\title{
KONTEKSTUALISASI PEMIKIRAN POLITIK JEAN JACQUES ROUSSEAU DI INDONESIA
}

\author{
Oleh: \\ Mhd. Alfahjri Sukri* \\ Institut Agama Islam Negeri Batusangkar \\ malfahjrisukri@iainbatusangkar.ac.id
}

\begin{abstract}
The research aims to analyze the contextualization of Jean Jacques Rousseau's political thought in Indonesia, including state of nature, social contracts, common will, freedom, and democracy. This study used a qualitative method to describe the results of the analysis. Data was obtained through books, journals, scientific articles and others. The result of research on state of nature is that before Indonesia existed there were already states in the form of kingdoms. As for the social contract established in Indonesia through Pancasila in a complicated way due to agreements and conflicts from several groups. But in the end Pancasila was able to unite the Indonesian nation to this day. Regarding the general will and freedom, in Indonesia, it is regulated in Pancasila and the 1945 Constitution of the Republic of Indonesia with various existing problems such as the abuse of general will and freedom that occurred during the Soekarno Guided Democracy and the Suharto Era. As for democracy, Rousseau views direct democracy as the best, while Indonesia is more familiar with representative democracy based on deliberation.
\end{abstract}

Keywords: Jean Jacques Rousseau, Social Contract, State of Nature, General Will, Democracy

\section{A. PENDAHULUAN}

Perkembangan pemikiran politik di dunia tidak dapat dilepaskan dari para pemikir dari Barat, salah satunya adalah Jean Jeacques Rousseau. Ia termasuk dalam pemikir politik terkenal yang karyanya masih digunakan hingga saat ini. Rousseau sendiri dididik dalam agama Calvins ortodoks. Rousseau mengkritik kehidupan modern Prancis yang mengagungkan akal yang mengakibatkan manusia kehilangan perasaannya, yang menimbulkan kesenjangan ekonomi, sosial, dan politik. Oleh karena itu, ia mengajak manusia untuk kembali ke alam, yaitu kondisi dimana manusia masih memiliki kebaikan-kebaikan alamiah. 
Karya Rousseau yang sangat terkenal adalah Du Social Contract (Kontak Sosial).

Du Social Contract ini bahkan menjadi salah satu karya yang menyulut semangat rakyat Prancis dalam melakukan revolusi untuk mencari kebebasan. Revolusi yang terjadi pada 17 Januari 1793, menyebabkan diguingkan dan dihukum matinya Raja Louis XVI karena dianggap tidak melaksanakan kehendak umum dan mengekang kebebasan. Dalam revolusi tersebut terkenal semboyan liberte (kebebasan), egaliter (persamaan), fraternite (persaudaraan). Rousseau dianggap menjadi salah satu tokoh yang mengisnpirasi revolusi tersebut (Muthmainnah, 2011)

Dalam kontrak sosial tersebut berbicara mengenai bangaimana hubungan rakyat dengan negara, mengenai kehendak umum, kebebasan, demokrasi dan lain sebagainya. Rousseau merupakan tokoh yang disatu sisi pejuang kebebasan namun disisi lain juga dapat menimbulkan negara totaliter. Kontrak sosialnya tersebut, banyak dipelajari oleh ilmuwan dan peneliti masa kini, termasuk di Indonesia. Di Indonesia, juga memiliki kontrak sosial dengan nama Pancasila yang merupakan buah pemikiran dan kesepakatan dari para tokoh-tokoh Indonesia dahulu. Kontrak sosial inilah yang menjadi landasan hidup bangsa Indonesia, sehingga ia harus dijalankan agar terbentuknya negara yang makmur dan sejahtera.

Maka menjadi sangat menarik melihat bagaimana pandangan- pandangan Rousseau dalam kontrak sosial yang dikeluarkannya dengan melihat kontrak sosial yang terjadi di Indonesia, karena kontrak sosial yang dipaparkan oleh Rousseau tidak sepenuhnya sama dengan apa yang terjadi dalam prakteknya di Indonesia. Oleh karena itu, penelitian ini berusaha untuk menjawab bagaimana kontekstualisasi pemikiran Rousseau tersebut dalam kehidupan politik negara Indonesia, mulai dari state of nature, terbentuknya Indonesia dengan kontrak sosial, praktik kehendak umum dan kebebasan serta implementasi demokrasi di Indonesia.

\section{B. METODE PENELITIAN}

Penelitian ini menggunakan metide kualitatif. Sugiyono (2012) menyebutkan, metode kualitatif bisa digunakan untuk meneliti serta menganalisis objek yang bersifat alamiah. Sedangkan menurut Cresswell, penelitian kualitatif merupakan metode yang dipakai dalam mengekplorasi masalah serta memahami gejala yang sentral (Ritchie \& Lewis, 2003) Di samping itu, penelitian kualitatif penekanannya bukan pada "angka" melainkan pada "kata" dengan instrument kuncinya adalah peneliti sendiri (Margret et al., 2014) Data diperoleh melalui artikel ilmiah, jurnal, buku dan sumber sejenis lainnya yang membahas tentang pemikiran J.J. Rousseau dan juga yang berkaitan dengan Indonesia. Hasil dan pembahasannya disajikan serta dianalisis secara deskriptifanalitis dengan penggambaran bagaimana kontekstualisasi pemikiran J.J. Rousseau di Indonesia. 


\section{HASIL DAN PEMBAHASAN}

\section{Sejarah Singkat JJ Rousseau dan Pemikirannya}

Sebelum masuk ke dalam pemikiran Jean Jacques Rousseau, ada baiknya kita sedikit mengenal sejarah dan latar belakang pemikirannya. Rousseau dilahirkan di Geneva, Swiss pada tanggal 28 Juni 1712. Rousseau dididik dalam agama Calvins ortodoks. Ia diasuh oleh ayahnya yang bernama Isac Rousseau yang bekerja sebagai tukang jam dan guru tari. Ayahnya sering menceritakan kisah-kisah romantis kepadanya setiap malam. Namun ketika ia berumur 10 tahun, ayahnya melarikan diri dari Geneva untuk menghindari hukuman penjara. Kemudian ia diasuh oleh saudara ibunya. Didikan ayahnya yang sering menceritakan kisah-kisah romantis setiap malamnya, telah mengasah kepekaan dan perasaan romantisnya (McDonald, 1968)

Di tahun 1949, Rousseau menjadi terkenal karena karyanya yang berjudul Discourse on the Arts and Sciences yang memenangkan penghargaan yang diberikan oleh Akademi Dijon. Di tahun 1762, dua karyanya yaitu Social Contract dan Emile diterbitkan. Karya Emile ini jugalah yang mengakibatkan ia meninggalkan Paris, karena karyanya tersebut dikecam oleh parlemen Paris. Di tahun 1770, ia kembali ke Paris dan di Parislah ia menghabiskan tahun-tahun terakhirnya dengan mengalami delusi dan halusinasi. Dan kemudian meninggal pada tahun 1778 dalam keadaan sangat miskin (Schmandt, 2009)
Latar belakang serta pengalaman yang ia miliki mempengaruhi cara berpikirnya. Pemikiran Rousseau tidak lepas dari pengaruh masa kecilnya. Bagaimana dalam otobiografinya, Confessions, memperlihatkan kesan bahwa ayahnya merupakan figur yang mempengaruhi pembentukan watak dan pemikirannya. Bersama ayahnya dimasa kanak-kanaknya, ia menghabiskan malam demi malam dengan cerita-cerita klasik karya Plutarch yang merupakan tokoh pada masa Romawi kuno (Suhelmi, 2001) Karya Rousseau yang terkenal adalah Social Contract (Kontrak Sosial) yang terkenal sampai sekarang ini.

Dalam bukunya tersebut, ia paparkan mengenai state of nature, kehendak umum, kebebasan, dan demokrasi yang dijadikan pisau analisis dalam penelitian ini. State of nature adalah pandangan Rousseau mengenai keadaan alamiah manusia sebelum terbentuknya negara. State of nature ini hanya merupakan pandangan Rousseau yang bersifat hipotesis. Manusia dalam keaadaan alamiahnya adalah baik, ia memiliki 'kebaikan-kebaikan' alamiah. Manusia dalam kondisi alamiahnya tidak suka berperang, karena tidak memiliki rasa benci dan dendam. Perang dalam pandangan Rousseau bukanlah fenomena almiah, tapi fenomena sosial. Dalam kondisi alamiah, manusia memiliki kebebasan mutlak, yaitu kebebasan yang tidak terdapat keinginan manusia untuk menaklukkan sesamanya, bebas dari rasa takut, kebebasan dalam artian keadilan yang membuat manusia merdeka, dan 
kebebasan yang tidak menimbulkan anarki sosial (Suhelmi, 2001)

Dikarenakan keadaan tidak menentu dengan kebebasan alaminya, karena perperangan dan pertikaian bisa terjadi kapan saja, individuindividu kemudian sepakat untuk mengadakan perjanjian bersama berupa kontrak sosial. Maka terbentukalah negara yang merupakan produk kontrak sosial. Dimana individu-individu menyerahkan sebagaian kekuasaan, kebebasan serta hak mereka pada kekuasaaan bersama. Kekuasaan inilah yang nantinya disebut dengan negara atau kedaulatan rakyat. Dalam suatu negara, kebebasan individu tidak hilang, namun dijamin oleh negara. Dalam hal ini, kebebasan ini tidak sama dengan kebebasan alami, namun merupakan kebebasan sipil, yaitu kebebasan yang disokong oleh kehendak umum (Noer, 1982) Kontrak sosial memberikan individu kekuatan kelompok dan kebebasan absolut.

Dalam kontrak sosial tersebut, Rousseau berbicara mengenai kehendak umum. Dalam pandangannya, kehendak umum adalah tuntutan kepentingan umum. Rakyat harus taat pada hukum yang bersendikan kehendak umum. Dan legitimasi negara dapat hilang apabila negara tidak dijalankan sesuai kehendak umum. Dengan begitu, negara yang absolut dapat berubah jadi negara yang menjalankan kehendak umum. Kehendak umum dapat diperoleh melalui penyaringan terlebih dahulu kehendak umum dengan memungut suara. Dengan pemungutan suara, maka kepentingan-kepentingan yang bersifat khusus dapat dieliminasi dan nantinya hanya menghasilkan kepentingan umum (Suseno, 2003) Dalam pandangan Rousseau, kehendak umum tidak bisa diwakilkan serta tidak bisa dibagi. Dan sifat kehendak umum ini selalu benar (Baramuli, 1992)

Berkaitan dengan pandangan Rousseau mengenai kebebasan, bagi Rousseau, kebebasan adalah hal yang mutlak bagi manusia. Kebebasan ini dijamin oleh negara, artinya kebebasan yang dimiliki tidak melanggar kehendak umum dan kebebasan untuk berbuat apa yang dikehendaki oleh negara (Baramuli, 1992) Pandangan Rousseau ini sebenarnya menujukkan paradoks kebebasan, yang dapat melahirkan negara totaliter, karena bebas dalam pengertian Rousseau adalah tidak bertentangan dengan kehendak umum dan negara.

Berkaitan dengan demokrasi, Rousseau tidak setuju dengan adanya lembaga perwakilan, termasuk partai politik, ia condong ke demokrasi lansung. Baginya, hubungan antara rakyat dengan negara adalah bersifat lansung, tidak diperantarai oleh lembaga apapun, termasuk dalam penyertaan rakyat dalam bidang legislatif. Bagi Rousseau, sistem perwakilan adalah sistem yang muncul dari kemalasan. Keikutsertaan masyarakat dalam pemerintahan haruslah bersifat lansung tanpa perantara. Oleh karena itu, Rousseau berpandangan bahwa negara yang baik adalah yang berukuran tidak begitu kecil maupun tidak terlalu besar. Kalau negara 
memiliki luas wilayah yang besar, maka susah terlaksananya keterlibatan rakyat secara lansung dalam pemerintahan, dan kalau terlalu kecil, akan sukar untuk mempertahankan diri. Dan oleh karena itulah ia mengganggap negara yang ideal adalah republik seluas polis atau Geneva (Noer, 1982)

\section{State of Nature dan Kontrak Sosial}

Dalam pandangan Rousseau, state of nature adalah kondisi alamiah manusia yang masih berisikan 'kebaikan-kebaikan' alamiah manusia sebelum terbentuknya negara sebelum terjadinya kontrak sosial. Dalam prakteknya di Indonesia, state of nature ini terjadi jauh sebelum Indonesia terbentuk, karena sebelum terbentuknya Indonesia, sudah terdapat negara-negara yang berbentuk kerajaan-kerajaan yang dipimpin oleh seorang raja, memiliki wilayah, rakyat, serta hukum yang berlaku. Oleh karena itu, penting untuk melihat kondisi Indonesia sebelum terjadinya kontrak sosial.

Sebelum terjadinya kontrak sosial di Indonesia, sudah terdapat kerajaan-kerajaan yang telah tumbuh dan berkembang sebelum datangnya penjajah dari Barat. Perjuangan dan perlawanan terus dilakukan oleh kerajaan-kerajaan tersebut, namun terus menghasilkan kegagalan. Memiliki kesamaan latar belakang karena sama-sama dijajah oleh Belanda dan Jepang, rakyat Indonesia kemudian bersatu. Sehingga muncullah Sumpah Pemuda pada 2728 Oktober 1928 yang menjadi tonggak nasional perlawanan bersama terhadap penjajah, sampai kemudian dengan diproklamasaikannya kemerdekaan Indonesia pada tahun 1945 dengan dasar negara Pancasila.

Adapun kontrak sosial di Indonesia, tercantum dalam Pancasila sebagai dasar negara, hasil konsensus the founding fathers Indonesia yang memiliki perjalanan sangat panjang serta perdebatan yang tidak ada habisnya. Pancasila sebagai kontrak sosial disampaikan oleh Onghokham (2006) dalam artikelnya pada surat kabar Suara Pembaharuan dengan judul "Kembalikan Pancasila sebagai Kontrak Sosial Bangsa". Pandangan Pancasila sebagai kontrak sosial ini kembali ia pertegas kumpulan tulisan bersama tokoh lainnya yang berjudul "Restorasi Pancasila: Mendamaikan Politik Identitas dan Modernitas" (Nasution \& Agustinus, 2006) Pancasila sebagai kontrak sosial ini juga disampaikan oleh Idrus Ruslam (2013) dalam tulisannya "Pemikiran Kontrak Sosial Jean Jacques Rousseau dan Masa Depan Umat Beragama". Penelitian ini menempatkan Pancasila sebagai kontrak sosial yang menyatukan bangsa Indonesia

Dalam menjelaskan bagaimana terjadinya kontrak sosial di Indonesia, tidak semudah apa yang disampaikan oleh Rousseau. Ada pertarungan ideologi di dalamnya. Perumusan mengenai dasar negara ini sebenarnya mulai dibicarakan pada masa persidangan pertama BPUPKI (Badan Penyelidik Usaha-Usaha Persiapan Kemerdekaan Indonesia) yang disahkan oleh Jepang pada 29 April 1945. Pembentukan BPUPKI 
merupakan realisasi janji Jepang berjanji menjadikan Indonesia negara merdeka. Tugas BPUPKI adalah memberikan gambaran tentang dasar hukum negara, sistem pemerintahan, dan bentuk negara (Sulato \& Yunarti, 2010)

Pancasila yang lahir dari gagasan Soekarno pada 1 Juni 1945 sebagai respon terhadap permintaan Rajdiman Wediodiningrat mengenai dasar negara Indonesia . Pandangan Soekarno ini disepakati sebagai konsensus bersama. Dalam perjalanannya kemudian Soekarno membentuk panitia kecil yaitu Panitia Sembilan yang beranggotakan 9 orang yang membahas rancangan Pembukaan Undang-Undang Dasar Negara Republik Indonesia, didalamnya termuat Dasar Negara. Hal ini merupakan inisiatif Soekarno untuk menyatukan kelompok Islam dengan kelompok kebangsaan, karena kelompok Islam menginginkan dasar negara Islam bagi Indonesia, yang juga sebelumnya keterwakilan umat Islam di BPUPKI juga sedikit (Latif, 2011)

Panitia Sembilan inilah yang kemudian melahirkan "Piagam Jakara", dan juga dari panitia ini kemudian dalam Muqaddimah Rancangan Pembukaan UndangUndang Negara Republik Indonesia dimasukkan kata-kata "Atas berkat rahmat Allah Yang Mahakuasa dan dengan didorong oleh keinginan luhur, supaya berkehidupan kebangsaan yang bebas..." yang mencerminkan penyatuan kelompok Islam dengan kebangsaan. Piagam Jakarta juga melahirkan rumusan dasar negara berdasarkan Pancasila dengan adanya sedikit perubahan pada kata-kata dan urutannya. Perubahan tersebut juga terjadi pada Sila Ketuhanan yang dipindah menjadi sila pertama yang ditambah dengan kata-kata "dengan kewajiban menjalankan syari'at Islam bagi pemeluk-pemeluknya" yang kemudian dikenal dengan tujuh kata sila pertama (Latif, 2011) Penambahan tujuh kata ini sebagai bentuk pengakuan negara terhadap Islam yang telah berjuang dengan tumpah darah untuk mempertahankan dan menyatukan Indonesia.

Hasil rumusan ini kemudian dibawa ke sidang kedua BPUPKI (10-17 Juli 1945) Dan hasil rumusan ini mendapat pertentangan dari golongan lain terutama non Islam, yang akhirnya menimbulkan perdebatan pro-kontra terhadap tujuh kata sila pertama, serta pasal-pasal lain seperti syarat agama untuk presiden dan agama resmi negara. Namun kemudian, Piagam Jakarta ini tetap diakui hingga akhir 17 Juli 1945, dan Piagam Jakarta inilah yang kemudian menjadi dasar dari proses pembentukan UUD 1945 berdasarkan Piagam Jakarta (Latif, 2011)

Pada akhirnya rancangan UUD disepakati pada 16 Juli 1945 oleh BPUPKI, kecuali oleh Muhammad Yamin dan anggota kebangsaan yang masih menganggap tujuh kata tidak sesuai dengan negara Indonesia. Masalah ini kemudian berlanjut dalam PPKI (Panitia Persiapan Kemerdekaan Indonesia) yang menggantikan BPUKI. PPKI bertugas untuk mempercepat kemerdekaan Indonesia dan mempersiapkan konstitusi. Pada 17 Agustus 1945 
proklamasi dibacakan, dan Indonesia merdeka. Soekarno dan Hatta kemudian dipilih oleh PPKI sebagai Presiden dan Wakil Presiden Indonesia pada 18 Agustus 1945. PPKI juga menyetujui naskah Piagam Jakarta dengan penghapusan tujuh kata sila pertama dan diganti dengan kata "Yang Maha Esa", sehingga menjadi "Ketuhanan Yang Maha Esa". Dan pasal 6 ayat 1 yang dulunya berbunyi bahwa agama presiden haruslah beragama Islam kemudian ditukar dengan presiden adalah orang Asli Indonesia. Pasal 29 ayat 1 diubah menjadi negara berpondasikan Ketuhana Yang Maha Esa (Ilyas, 2020) Perubahanperubahan ini juga sebenarnya memiliki banyak polemik, intrik, dan permasalahan yang sebagian umat Islam sebut sebagai penghianatan terhadap perjuangan umat Islam.

Umat Islam menerima perubahan terhadap Pancasila saat itu dikarenakan perkataan Soekarno bahwa dasar negara tersebut bersifat sementara, dan akan dibahas lebih lanjut dalam Konstituante yang bertugas untuk menyiapkan konstitusi dan dasar negara yang permanen. Namun, kemudian Kontituante yang sudah terbentuk dibubarkan oleh Soekarno karena dianggap tidak melahirkan kesepakatan, sehingga melahirkan Dekrit Presiden 1959 dengan lahirnya Demokrasi Terpimpin (Lubis, 2020) Sidangsidang dalam Majelis Konstituante memang berjalan alot, terutama dalam pembahasan dasar negara. Dalam sidang tersebut terdapat tiga pilihan dasar negara yaitu Pancasila, Sosial Ekonomi, dan Islam.
Suara yang berimbang antara pendukung Islam dan Pancasila mengakibatkan sidang jalan di tempat. Sebelum dibubarkan, Presiden Soekarno sebelumnya sudah menganjurkan kepada Konstituante agar dasar negara kembali ke UUD 1945 dan Pancasila, namun tidak ada keputusan yang dihasilkan oleh Konstituante. Syarat 2/3 suara untuk mengubah dasar negara tak terpenuhi, Dan diperparah dengan anggotaanggota Konstituante yang lain yang tidak lagi mau ikut dalam sidangsidang selanjutnya, sehingga menjadi salah satu alasan bagi Soekarno mengumumkan Dekrit Presiden 5 Juli 1959, serta Indonesia kembali pada Pancasila dan UUD 1945 (Lubis, 2020) Di samping juga terdapat faktor politik dari munculnya dekrit tersebut yaitu dikarenakan posisi Surkano sebagai presiden dalam sistem pemerintahan parlementer saat itu sangatlah kecil. Dengan dikeluarkannya dekrit Presiden dengan dukungan militer, Soekarno melanggengkan kekuasaannya menjadi diktator pertama di Indonesia.

Dari paparan di atas, terlihat terjadinya kontrak sosial di Indonesia yang menghasilkan Pancasila tidak semudah yang dipaparkan oleh Rousseau. Dalam kontrak sosial Rousseau dipaparkan bahwa kontrak sosial mucul dengan masing-masing individu menyerahkan hak-hak dan kebebasan kepada kekuasaan bersama dalam bentuk negara untuk melindungi mereka. Adapun dalam kontrak sosial masyarakat Indonesia (Pancasila), kesepakatan ini tidak lansung diterima oleh masing-masing golongan. Banyak perdebatan dan 
perbedaaan pandangan yang harus dilalui, dan bahkan pada akhirnya ada bentuk pemaksaan kehendak yang dilakukan oleh Soekarno dengan Dekrit Presidennya. Hal ini menunjukkan bahwa terbentuknya kontrak sosial di Indonesia mengalami perjalanan yang panjang dan rumit yang telah melahirkan Pancasila.

\section{Dalam}

pembentukan Pancasilapun, tidak semua rakyat Indonesia ikut andil di dalamnya, namun yang ikut adalah perwakilanperwakilan golongan, yang masingmasing golongan memberikan pendapat dan pandangannya mengenai dasar negara. Hal ini terjadi juga karena kondisi perperangan saat itu, yang mengharuskan untuk mengambil langkah cepat untuk merumuskan dasar negara, serta juga budaya Indonesia yang lebih mengenal jalan musyawarah dengan perwakilan.

Bagaimanapun, lahirnya kontrak sosial Indonesia berupa Pancasila adalah hal yang luar biasa. Pancasila adalah kontrak sosial yang dapat menyatukan rakyat Indonesia, yang nilai-nilainya seharusnya dijalankan dalam kehidupan bernegara. Namun, seiring berjalannya waktu dan efek globalisme yang melahirkan individualisme mengakibatkan nilainilai Pancasila semakin pudar dan hilang ditelan masa.

\section{Kehendak Umum dan Kebebasan}

Menurut Rousseau kehendak umum merupakan tuntutan kepentingan umum, dan hukum yang merupakan refleksi dari kehendak umum. Adapun penyaringan kepentingan individu menjadi kepentingan umum adalah dengan pemungutan suara (suara mayoritas). Kehendak umum inilah yang menunjukkan kedaulatan rakya.

Pada prakteknya, kehendak umum di Indonesia tidak sepenuhnya sama dengan apa yang dipaparkan oleh Rousseau. Kehendak umum di Indonesia yang menggambarkan kedaulatan rakyat diatur oleh UUD 1945 yang sempat mengalami amademen. Sebelum amademen, Pasal 1 ayat (2) UUD 1945 berbunyi "Kedaulatan adalah ditangan rakyat dan dilakukan sepenuhnya oleh Majelis Permusyawaratan Rakyat", namun setelah amademen, Pasal 1 ayat (2) UUD 1945 berbunyi "Kedaulatan berada di tangan rakyat dan dilaksanakan menurut UndangUndang Dasar". Posisi MPR (Majelis Permusyawaratan Rakyat) berubah, bukan selaku pemegang kekuasaan tertinggi lagi.

Di Indonesia rakyat berdaulat dengan perwakilannya yang sudah mereka pilih dalam badan-badan atau perwakilan-perwakilan rakyat seperti DPR dan DPD. Lembaga-lembaga inilah yang menampung aspirasi rakyat. Bukan rakyat yang ikut lansung dalam menentukan suatu peraturan seperti yang dipaparkan oleh Rousseau. Indonesia masih mengenal sistem musyawarah perwakilan yang terdapat dalam sila ke empat. Rakyat saat sekarang ini memilih lansung para perwakilan dan pemimpin mereka. Artinya secara kasat mata, rakyat memiliki 
kedaulatan tertinggi, selama mentaati hukum yang telah ditetapkan.

Dalam perjalanan sejarahnya, sebelum UUD 1945 di amademen, UUD Indonesia mengalami beberapa kali perubahan, yaitu mulai dari UUD 1945 yang diterapkan mulai dari tahun 1945 hingga 1949; Konstitusi Republik Indonesia Serikat (RIS) dari tahun 1949 hingga 1950; UndangUndang Dasar Sementara (UUDS) yang diterapkan pada 1950 hingga 1959; hingga kemudian kembali ke UUD 1945 setelah Soekarno mengeluarkan Dekrit pada 1959; berulah kemudian dilakukan amademen UUD 1945 setelah Soeharto lengser. Artinya, UndangUndang Dasar sebagai salah satu representasi kehendak umum masyarakat Indonesia juga dapat mengalami perubahan yang dapat dipengaruhi oleh kondisi sosial politik Indonesia sendiri, serta perubahan dilakukan ketika UUD yang ada dianggap tidk lagi sesuai dengan zaman. Namun, walaupun UUD dapat dilakukan amademen, Pancasila sebagai dasar negara tetap berlaku dan tidak diubah.

Di samping itu, penyelewengan atas kehendak umum juga terjadi di Indonesia, ketika Orde Lama pimpinan Soekarno maupun Orde Baru pimpinan Soeharto. Soekarno melanggar hak sipil dan konstitusi dengan menggangkat dirinya sebagai presiden seumur hidup serta melanggar prosedur lainnya dalam bernegara. Hal ini berlanjut pada masa Orde Baru ketika alasan untuk "kepentingan umum" dipakai untuk membungkam lawan politiknya, serta kontrol negara yang kuat oleh Soeharto.

Adapun kebebasan dalam pengertian bangsa Indonesia, telah diatur dalam UUD 1945, termasuk di dalamnya mengenai Hak Asasi Manusia (HAM). UUD melindungi kebebasan beragama, berpendapat, dan berserikat yang telah diatur sedemikian rupa. Dan bahkan kebebasan dalam artian yang dianut oleh bangsa Indonesia memiliki makna yang luas, tidak hanya menuntut kebebasan dalam negara sendiri, namun juga memperjuangkan kebebasan dan kemerdekaan negara lain sebagaimana yang tercantum dalam Mukaddimah (Pembukaan) UUD 1945, yang penggalannya berbunyi "Bahwa sesungguhnya kemerdekaan itu ialah hak segala bangsa dan oleh sebab itu, maka penjajahan diatas dunia harus dihapuskan karena tidak sesuai dengan perikemanusiaan dan perikeadilan." Dalam pasal $28 \mathrm{E}$ ayat 3 UUD 1945 juga menyatakan bahwa "Setiap orang berhak atas kebebasan berserikat, berkumpul dan mengeluarkan pendapat.”

Dalam implementasinya, kebebasan ini juga mendapatkan rintangan, khususnya pada masa Demokrasi Terpimpin Soekarno dan Orde Baru, bahkan hingga saat ini. Pada masa Demokrasi Terpimpinnya Soekarno terjadi berbagai pengekangan terhadap kebebasan. Terjadi 184 pembredelan terhadap pers serta 224 tindakan anti pers lainnya yang dilakukan oleh Soekarno. Selama rentang tahun 1957 hingga 1965 menurut Mahfud MD tercatat tiga bentuk pelanggaran 
HAM yang dilakukan Soekarno yaitu pembredelan 184 kasus, memenjarakan 30 kasus, dan penahanan 30 kasus. Di tambah pada masa ini Partai Sosialis Indonesia (PSI) dan partai Masyumi dibubarkan. Berbagai aturan dalam bentuk Keputusan Presiden dikeluarkan dalam mengekang kebebasan berekspresi dan berorganisasi masyarakat (Nurhardianto, 2014)

Sedangkan kondisi kebebasan masyarakat dalam berekspresi dan berserikat lebih parah lagi pada masa Soeharto. Kasus-kasus pelanggaran HAM banyak terjadi pada masa ini. Penyederhanaan partai dilakukan dengan satu golonga karya yaitu Glokar dan dua partai yaitu Partai Persatuan Pembangunan (leburan partai Islam), dan Partai Demokrasi Indonesia (leburan partai nasionalis sekuler). Masa ini Soeharto juga mengawasi secara ketat media massa, kegiatan mahasiswa di kampus dan LSM (Nurhardianto, 2014). Banyak pelanggaraa HAM di masa Soeharto seperti kasus nipah, kasus Aceh, kasus Papua, Kasus Timor Timur, kasus Tanjung Priok, Talang Sari, tuduhan komando Jihad, penembakan misterius dan kasus HAM lainnya (Anif \& Dewi, 2017) Perlindungan atas HAM dan juga jaminan kebebasan berekspresi dan berserikat barulah kemudian membaik pasca jatuhnya Soeharto dan Indonesia memasuki era Reformasi. Walaupun memang masih terdapat permasalahan dalam kebebasan berpendapat, khususnya berkaitan dengan kasus-kasus mengeai UU No. 11 Tahun 2008 tentang Informasi dan
Transaksi Elektronik (ITE) yang saat ini menjadi perdebatan.

Dari paparan di atas tampak bahwa, kehendak umum dan kebebasan yang dipaparkan Rousseau, terdapat dalam negara Indonesia. Namun, dalam prakteknya di Indonesia sendiri memiliki dinamikan dan berbagai permasalahannya sendiri.

\section{Demokrasi}

Demokrasi yang terdapat dalam pikiran Rousseau adalah demokrasi lansung tanpa perwakilan, karena Rousseau mengganggap adanya perwakilan rakyat sebagai bentuk kelemahan dan kemalasan. Serta Rousseau tidak menyukai adanya partai politik.

Pandangan Rousseau tersebut berbanding terbalik dengan paktek yang dilakukan di Indonesia. Di Indonesia, lebih mengenal demokrasi permusyawaratan dengan perwakilanperwakilannya di DPR dan DPD. Adapun partai politik, hidup subur di awal-awal kemerdekaan Indonesia sampai saat sekarang ini, walaupun kebebasan berpartai politik tersebut pernah dikekang di masa Demokrasi Terpimpin dan masa Orde Baru.

Demokrasi permusyawaratan ini berakar pada tradisi dan budaya serta nilai-nilai religius yang dianut Indonesia untuk mewujudkan semangat kekeluargaan dan keadilan sosial. Oleh sebab itu, rakyat memiliki perwakilannya di DPR dan DPD untuk menyampaikan aspirasi mereka, serta rakyat akan melihat bagaimana kualitas dari wakil yang 
telah mereka pilih secara lansung tersebut. Rakyat ikut berpatisipasi dalam perpolitikan di Indonesia, serta menunjukkan bahwa rakyat memiliki kedaulatan.

Yudi Latif (2011) menyebutkan, empat prasyarat keputusan dikatakan benar dalam demokrasi permusyawaratan, yaitu pertama, dedikasi bagi kepentingan umum; kedua, imparsial dalam artian keputusan mempertimbangkan serta melibatkan semuaa pihak; ketiga, berdasarkan pada rasinal dan adil; dan keempat, orientasinya jauh ke depan untuk kepentingan bangsa.

Demokrasi di Indonesia secara subtansi merupakan demokrasi didasarkan pada musyawarah. Hal ini berdasarkan pada Pancasila di sila ke empat yang berbunyi "Kerakyatan yang dipimpin oleh hikmat kebijaksanaan dalam permusyawaratan/perwakilan".

Namun, dalam prakteknya di Indonesia, walaupun esensinya sama namun bentuk demokrasi di Indonesia juga mengalami perubahan sesuai kondisi sosial politik seperti Demokrasi Liberal ketika Indonesia menganut Sistem Pemerintahan Parlementer dimana partai politik memiliki kekuatan yang kuat; Demokrasi Terpimpinnya Soekarno yang memusatkan kekuasaan pada Soekarno; Demokrasi Pancasilanya Soeharto yang menjadikan Pancasila sebagai alat politiknya; serta Demokrasi era Reformasi saat ini yang kembali mengembalikan HAM masyarakat Indonesia.

Pandangan demokrasi Rousseau dan Indonesia memang berbeda. Ini diakibatkan oleh pandangan Rousseau yang cenderung idealis yang menginginkan negara dengan wilayah yang tidak besar dan juga tidak kecil, sehingga semua rakyat ikut lansung dalam menentukan kebijakan negara atau keputusan politik. Berbeda dengan Indonesia yang memiliki luas wilayah yang besar, sehingga tidak memungkinkan untuk semua rakyat ikut lansung dalam pengambilan keputusan, oleh karena itu rakyat memilih perwakilannya untuk menyampaikan aspirasi mereka. Ini juga tercantum di sila ke empat dalam Pancasila yang berbunyi "Kerakyatan yang dipimpin oleh hikmat kebijaksanaan dalam permusyawaratan perwakilan".

Demokrasi permusyawaratan lebih mudah diterapkan di Indonesia, dibandingkan menerapkan demokrasi lansung dalam pandangan Rousseau. Dalam beberapa hal, rakyat Indonesia memilih lansung presiden dan perwakilan mereka di Parlemen, serta mempercayakan wakil-wakil tersebut dalam membawa aspirasi mereka.

\section{KESIMPULAN}

Pandangan Rousseau mengenai kontrak sosial, memiliki perbedaan dan persamaan ketika melihat kontekstualisasinya di Indonesia. State of nature terjadi jauh sebelum Indonesia terbentuk, karena sebelum terbentuknya Indonesia, sudah terdapat negara-negara yang berbentuk kerajaan-kerajaan. Dan Kontrak sosial yang tejalin di Indonesia melalui Pancasila terbentuk dengan cara yang tidak mudah, karena adanya penolakan serta pertentangan dari golongan-golongan 
yang ada. Mengenai kehendak umum dan kebebasan, di Indonesia, semuanya sudah diatur dalam Pancasila dan UUD 1945, namun juga mengalami dinamika, khususnya ketika penyelewengan kehendak umum dan pengekangan kebebasan pada masa Orde Lamanya Soekarno dan Orde Barunya Soeharto.. Berkaitan dengan demokrasi,

\section{Daftar Kepustakaan}

Anif, V., \& Dewi, G. M. (2017). Arah Politik Hukum Kebijakan Perlindungan HAM di Indonesia. Lex Scienta Law Review, 1(1).

Baramuli, A. (1992). Pemikiran Rousseau Dalam Konstitusi Amerika Serikat. Yayasan Sumber Agung.

Ilyas. (2020). Islam dan Kebangsaan: Pergumulan dalam BPUPKI, PPKI dan Piagam Jakarta. Buletin Al-Turas, 26(1).

Latif, Y. (2011). Negara Paripurna. PT. Gramedia Pustaka Utama.

Lubis, A. A. A. M. R. (2020). Politik Ruang NKRI: BPUPKI sampai Majelis Konstituante. Shar-E: Jurnal Kajian Ekonomi Hukum Syariah, 6(1).

Ma'arif, S. (2010). Menggugat Sejarah. Saga Arsy.

Margret, A., Ardiansa, D., Irwansyah, Ichwanuddin, W., \& Fajar, Y. (2014). Panduan Praktis Metode Penelitian Sosial. Pusat Kajian Politik Universitas Indonesia.

McDonald, L. C. (1968). Western Political Theory: From Its Origins to The Present. Harcourt Brace Javanovich.

Muthmainnah, L. (2011). State Of
Rousseau memandang demokrasi langsung yang paling baik, dan ini berbeda dengan praktek di Indonesia yang lebih menerapkan demokrasi perwakilan yang didasarkan pada permusyawaratan sesuai dengan sila ke empat Pancasila. Implementasi demokrasi di Indonesiapun juga mengalami perubahan dan permasalahannya..

Nature J.J. Rousseau dan Implikasinya Terhadap Bentuk Negara Ideal. Jurnal Filsafat, 21(1).

Nasution, I., \& Agustinus, R. (2006). Restorasi Pancasila: Mendamaikan Politik Identitas dan Modernitas. Brigthen Prees.

Noer, D. (1982). Pemikiran Politik di Negeri Barat. CV. Rajawali.

Nurhardianto, F. (2014). Politik Hukum HAM di Indonesia. Jurnal TAPIs, 10(2).

Onghokham. (2006). Kembalikan Pancasila sebagai Kontrak Sosial. Suara Pembarahuan.

Ritchie, J., \& Lewis, J. (2003). Qulitative Research Practice: A Guide for Social Science Students and Researches. Sage Publication.

Ruslam, I. (2013). Pemikiran Kontrak Sosial Jean Jacques Rousseau dan Masa Depan Umat Beragama. Al-Ad-YaN, 8(2).

Schmandt, H. J. (2009). Filsafat Politik: Kajian Historis dari Zaman Yunani Kuno Sampai Zaman Modern. Pustaka Pelajar.

Sugiyono. (2012). Metode Penelitian Kuantitatif Kualitatif dan $R \& D$. Alfabeta.

Suhelmi, A. (2001). Pemikiran Politik Barat. PT Gramedia 
Pustaka Utama.

Sulato, \& Yunarti, D. R. (2010). Konflik Di Balik Proklamasi: BPUPKI, PPKI, dan Kemerdekaan. Penerbit Buku Kompas.
Suseno, F. M. (2003). Etika Politik:

Prinsip-Prinsip Moral Dasar Kenegaraan Modern. PT. Gramedia Pustaka. 